\title{
Do Early Childhood Schools Have Contextual Effect on Child Development Aged 3-6 Years in Tanjung Jabung Timur, Jambi?
}

\author{
Dinda Septiani Hardilla'), Harsono Salimo'), \\ Eti Poncorini Pamungkasari3)
}

\author{
1)Masters Program in Public Health, Universitas Sebelas Maret \\ 2)Department of Pediatrics, Dr. Moewardi Hospital, Surakarta \\ 3)Faculty of Medicine, Universitas Sebelas Maret
}

\section{ABSTRACT}

Background: Early childhood development is a critical period in children's lives. The development index in early childhood in Indonesia is relatively low compared to other developing countries, which is $\mathbf{8 8 . 3 \%}$. Various factors that can influence early childhood development were the nutritional status of children, stimulation by parents, exclusive breastfeeding, dietary patterns, and parental characteristics. This study aimed to analyze the contextual influence of early childhood education on child development in Tanjung Jabung Timur, Jambi.

Subjects and Method: This was a cross sectional study conducted at 25 early childhood schools in Tanjung Jabung Timur, Jambi, from September to October 2019. A sample of 200 children aged 3-6 years old was selected by stratified random sampling. The dependent variable was child development. The independent variables were nutritional status, dietary pattern, exclusive breastfeeding, maternal education, maternal occupation, and family income. Child development was measured by The Indonesian child development pre-screening questionnaire. The other data were collected by questionnaire. The data were analyzed by a multilevel multiple logistic regression run on Stata 13.

Results: Early childhood development increased with good nutritional status $(b=1.88$; $95 \% \mathrm{CI}=$
0.48 to $3.28 ; \mathrm{p}=0.008)$, good dietary pattern $(\mathrm{b}=$ $1.58 ; 95 \% \mathrm{CI}=0.26$ to $2.91 ; \mathrm{p}=0.019)$, exclusive breastfeeding $(\mathrm{b}=0.64 ; 95 \% \mathrm{CI}=-0.69$ to 1.99 ; $\mathrm{p}=0.346)$, maternal education $\geq \operatorname{High}$ school $(\mathrm{b}=$ $2.45 ; 95 \% \mathrm{CI}=0.97$ to $3.92 ; \mathrm{p}=0.001$ ), and family income $\geq \operatorname{Rp~2,840,000~}(b=1.93 ; 95 \% \mathrm{CI}=0.32$ to $0.53 ; p=0.018$ ). Early childhood development decreased with maternal working outside the house $(\mathrm{b}=-1.42 ; 95 \% \mathrm{CI}=-2.66$ to $-0.17 ; \mathrm{p}=$ 0.025). Early childhood school had low effect on child development with intra-class correlation= $10.09 \%$.

Conclusion: Early childhood development was influenced by nutritional status, dietary patterns, exclusive breastfeeding, maternal education, maternal employment, and family income. Early childhood education has contextual influence on child development.

Keywords: child development, early childhood education

\section{Correspondence:}

Dinda Septiani Hardilla. Masters Program in Pub lic Health, Universitas Sebelas Maret. Jl. Ir. Su tami 36A, Surakarta, Central Java. Email: dinda septianihardilla15@gmail.com. Mobile: 082373 568987.

Cite this as:

Hardilla DS, Salimo H, Pamungkasari EP (2020). Do Early Childhood Schools Have Contextual Effect on Child Development Aged 3-6 Years in Tanjung Jabung Timur, Jambi? J Matern Child Health. 5(2): 120-128. https://doi.org/10.26911/thejmch.2020.05.02.01

(c) (i) (-) Journal of Maternal and Child Health is licensed under a Creative Commons Attribution-Non Commercial-Share Alike 4.o International License.

\section{BACKGROUND}

Achievement of appropriate growth and development becomes one of the deter- minants of children's subsequent lives (Bornstein et al., 2012). Early childhood development requires attention to be able to reach 
the optimal point in developing. Support is needed from the surrounding environment to achieve appropriate development of environment. It can support the family environment and early childhood education environment that can provide early education in improving child development (Black et al., 2016).

The index of early childhood development in Indonesia in 2018 is lower than other developing countries, which is $88.3 \%$. Various factors that can influence early childhood development such as the nutritional status of children, the success of exclusive breastfeeding, parental attention, stimulation by parents, and income or economic status of parents are one of the important factors that can affect early childhood development (Moriguchi et al., 2019; Siswani et al., 2016).

Early childhood education is one of the tools used to provide stimulation and training for children. Provision of stimulation in early childhood can improve child development for the better and in accordance with the age of the child (Black et al., 2016; Hati et al., 2016). Early childhood education gives a good influence on children's development both motor development, cognitive, language, emotions, and behavior of early childhood (Putriarsih et al., 2017).

A study by Rao et al., (2017) stated that stimulation provided to children in a child's educational environment can affect a child's brain that develops very rapidly during early life of a child. Early childhood education contains programs that target early childhood's intelligence and health. Education provided by early childhood can have a positive impact on overall physical, mental quality, child interaction, and child development (Proulx et al., 2019; Zacarias et al., 2019).

Different educational environments give children the access to stimulate development and children have experience to optimize development (Putriarsih et al., 2017).
This study aimed to analyze the contextual influence of early childhood education on child development in Tanjung Jabung Timur, Jambi.

\section{SUBJECTS AND METHOD \\ 1. Study Design}

This was an observational analytic method with cross sectional approach. This study was conducted in 25 early childhood schools in Timur Tanjung Jabung, Jambi, Indonesia, from September to October 2019.

\section{Population and Sample}

The population in this study were children aged 3-6 years old who attended 25 Early Childhood Education in Tanjung Jabung Timur. A sample of 200 study subjects was selected by stratified random sampling.

\section{Study Variables}

The dependent variable in this study was early childhood development. The independent variables in this study were the nutritional status of children, children's dietary patterns, the success of exclusive breastfeeding, maternal education, maternal employment, and family income.

\section{Operational Definition of Variables}

Nutritional status was assessed by measuring child's weight based on age (weight for age). Measuring instruments used are weight scales and age of the child based on the date of birth. The measurement scale was continuous and transformed into dichotomous, coded o for poor nutrition status and 1 for good nutrition status.

Dietary Pattern was assessed by measuring children's dietary patterns based on food frequency questionnaire (FFQ). The measuring instrument used was the FFQ questionnaire. The measurement scale was continuous and transformed into dichotomous, coded o for poor dietary pattern and 1 for good dietary pattern.

Exclusive Breastfeeding seen from the success of children breastfeeding exclusively 
for 6 full months without food and other drinks. The data were collected by questionnaire. The measurement scale was continuous and transformed into dichotomous, coded $o$ for no exclusive breastfeeding and 1 for exclusive breastfeeding.

Maternal education measured by looking at the last formal education of mothers of early childhood. The data were collected by questionnaire. The measurement scale was categorical, coded o for $<$ Senior high school and 1 for Senior high school.

Maternal employment measured by looking at the daily activities of mothers who do work outside the home or at home. The data were collected by questionnaire. The measurement scale was categorical, coded o for working at home $1=$ working outside the home.

Family Income measured by assessing income per capita per month from the average income received either fixed or not every month. The data were collected by questionnaire. The measurement scale was continuous and transformed dichotomous, coded o for income ( $<$ Rp 2,840,ooo) and 1 for high income ( $\geq \operatorname{Rp~2,840,000).~}$

Child development measured by looking at the ability or function of all child organ systems in accordance with the provisions of development based on age. The data were collected by questionnaire. The measurement scale was continuous and transformed into dichotomous, coded $\mathrm{o}$ for not suitable $1=$ suitable.

\section{Data Analysis}

Univariate analysis generally described each of the variables studied included child development, nutritional status, dietary pattern, exclusive breastfeeding, maternal education, maternal occupation, and family income. Bivariate analysis was performing to explain the effect of each independent variable on child development. Multivariate analysis was conducted to explain the effect of more than one independent variable, namely nutritional status, dietary pattern, exclusive breastfeeding, maternal education, maternal occupation, and family income, as level 1 on the development of children aged 3-6 years old. Variable at level 2 was early childhood school.

\section{Research Ethic}

This study was conducted based on research ethics, namely informed consent, anonymity, confidentiality, and ethical worthiness. Ethics permission in this study was obtained from the Health Research Ethics Commission of Dr. Moewardi Hospital, Surakarta, Indonesia, No. 995/VIII/HREC/2019.

\section{RESULTS}

\section{Sample Characteristics}

The categorical data sample described the continuous data of each study variable including child development, nutritional status, dietary patterns, and family income. Table 1 showed sample characteristics in continuous data.

Table 1. Sample characteristics of continuous data

\begin{tabular}{lccccc}
\hline \multicolumn{1}{c}{ Variables } & n & Mean & SD & Min. & Max. \\
\hline Child's Development & 200 & 7.68 & 1.43 & 4 & 10 \\
Nutritional Status (weight for age) & 200 & -1.47 & 1.50 & -4 & 3 \\
Dietary Pattern & 200 & 9.36 & 2.61 & 5 & 14 \\
Family Income (Rupiah) & 200 & $2,928,000$ & $1,425,000$ & 500,000 & $9,000,000$ \\
\hline
\end{tabular}

\section{Univariate analysis}

Table 2 showed sample characteristics in categorical data. Table 2 showed that a total of
113 children (56.6\%) experienced good nutritional status. Children with good diet were 115 children (57.5\%). 109 children were 
Hardilla et al. / Do Early Childhood Schools Have Contextual Effect

exclusively breastfed (54.5\%). Low maternal education of 107 children (53.5\%). There were 142 children with mothers who worked at home (71\%). Children with low family income $(\operatorname{Rp~2,840,000)}$ were 112 children $(56 \%)$.

Table 2. Sample characteristics of categorical data

\begin{tabular}{|c|c|c|c|}
\hline \multicolumn{2}{|c|}{ Variables } & $\begin{array}{c}\text { Frequen } \\
\text { cy (n) }\end{array}$ & Percentage (\%) \\
\hline \multirow[t]{2}{*}{ Child's Development } & Not appropriate & 90 & 45.0 \\
\hline & Appropriate & 110 & 55.0 \\
\hline \multirow[t]{2}{*}{ Nutritional Status } & Poor & 87 & $43 \cdot 5$ \\
\hline & Good & 113 & 56.5 \\
\hline \multirow[t]{2}{*}{ Dietary Pattern } & Poor & 85 & 42.5 \\
\hline & Good & 115 & $57 \cdot 5$ \\
\hline \multirow[t]{2}{*}{ Exclusive Breastfeeding } & No & 91 & $45 \cdot 5$ \\
\hline & Yes & 109 & $54 \cdot 5$ \\
\hline \multirow[t]{2}{*}{ Maternal Education } & Low $(<\mathrm{HS})$ & 107 & 53.5 \\
\hline & High ( $\geq$ HS) & 93 & 46.5 \\
\hline \multirow[t]{2}{*}{ Maternal Employment } & Work at home & 142 & 71.0 \\
\hline & Work outside the home & 58 & 29.0 \\
\hline \multirow[t]{2}{*}{ Family Income } & Low $(<\operatorname{Rp} 2,840,000)$ & 112 & 56.0 \\
\hline & High $(\geq \operatorname{Rp} 2,840,000)$ & 88 & 44.0 \\
\hline
\end{tabular}

\section{The result of multilevel analysis}

Multilevel analysis used multilevel multiple logistic regression methods and analyzed by using Stata 13. Table 3 showed that there were effects of nutritional status, dietary patterns, exclusive breastfeeding, maternal education, maternal employment, and family income on child development.

The nutritional status of the child was $\operatorname{good}(\mathrm{b}=1.88 ; 95 \% \mathrm{CI}=0.48$ to $3.28 ; \mathrm{p}=$ o.0o8), the child's dietary pattern was good $(b=1.58 ; 95 \% \mathrm{CI}=0.26$ to $2.91 ; \mathrm{p}=0.019)$, exclusive breastfeeding $(\mathrm{b}=0.64 ; 95 \% \mathrm{CI}=-$ 0.69 to $1.99 ; \mathrm{p}=0.346)$, maternal education $\geq$ Senior high school $(b=2.45 ; 95 \% \mathrm{CI}=0.97$ to $3.92 ; \mathrm{p}=0.001$ ), family income $\geq \mathrm{Rp}$ $2,840,000(b=1.93 ; 95 \% \mathrm{CI}=0.32$ to 0.53 ; $\mathrm{p}=$ 0.018) increased child development. Maternal employment outside the home $(\mathrm{b}=$ $1.42 ; 95 \% \mathrm{CI}=-2.66$ to $-0.17 ; \mathrm{p}=0.025$ ) decreased the development of early childhood. Early childhood schools had contextual effect on child development with intra-class correlation $(\mathrm{ICC})=10.09 \%$.

Table 3. Multilevel multiple logistic regression analysis on the determinants of child development

\begin{tabular}{|c|c|c|c|c|}
\hline \multirow{2}{*}{ Independent Variables } & \multirow{2}{*}{ b } & \multicolumn{2}{|c|}{ 95\% CI } & \multirow{2}{*}{$\mathbf{p}$} \\
\hline & & Lower limit & Upper limit & \\
\hline \multicolumn{5}{|l|}{ Fixed effect } \\
\hline Nutritional status (Good) & 1.88 & 0.48 & 3.28 & 0.008 \\
\hline Dietary pattern (Good) & 1.58 & 0.26 & 2.91 & 0.019 \\
\hline Exclusive breastfeeding (Yes) & 0.64 & -0.69 & 1.99 & 0.346 \\
\hline Maternal education $(\geq \mathrm{HS})$ & 2.45 & 0.97 & 3.92 & 0.001 \\
\hline Maternal employment (Outside the house) & -1.42 & -2.66 & -0.17 & 0.025 \\
\hline Family income $(\geq 2,840,000)$ & 1.93 & 0.32 & 3.53 & 0.018 \\
\hline \multicolumn{5}{|l|}{ Random effect } \\
\hline \multicolumn{5}{|l|}{$\mathrm{N}$ observation $=200, \mathrm{~N}$ group $=25$} \\
\hline \multicolumn{5}{|l|}{ Group average $=8, \min =8, \max =8$} \\
\hline \multicolumn{5}{|l|}{ Log likelihood $=-2.96 p=0.269$} \\
\hline $\mathrm{ICC}=10.09 \%$ & & & & \\
\hline
\end{tabular}




\section{DISCUSSION}

1. The effect of nutritional status on child development

Nutritional status has a significant influence on early childhood development. Children with good nutritional status experienced development by 1.88 units higher than children with poor nutritional status. Nutritional status was one of the main factors that can affect children's growth, health and development. Nutritional status, the level of gross motor development and fine motor development influenced each other (Solihin et al., 2013).

One third of children under five in developing countries have growth and development retardation caused by malnutrition. Low nutritional status in children can inhibit development in the cognitive and social aspects in children (Walker et al., 2007).

Poor nutritional status has the potential for development that was not age-appropriate. Children with good nutritional status would have normal development compared to children with poor nutritional status. Balanced nutrition in children was highly recommended to be able to maintain good child's nutritional status. Children who experienced lack of nutritious food would cause the child to be weak and inactive, resulting in growth retardation and child development (Lindawati, 2013; Putri et al., 2016).

2. The effect of dietary pattern on child development

Dietary patterns have a significant effect on early childhood development. Children with good eating patterns developed according to 1.58 units higher than children with poor dietary patterns. Dietary pattern contributed $3 \%$ in improving early childhood development. Dietary pattern was assessed from the suitability of the frequency of eating per day in early childhood. Early childhood still needed special attention to improve children's dietary patterns so that it did not interfere with children's development at an early age (Risma et al., 2013). Parents with proper knowledge about dietary patterns can monitor children to achieve appropriate development so as to avoid deviations and developmental delays of children at an early age (Husnah, 2015). Inappropriate dietary patterns can result in malnutrition so that it can be a factor that can affect the child's growth and development (Alderman et al., 2017; Solihin et al., 2013).

\section{The effect of exclusive breastfeed-} ing on child development

Children with exclusive breastfeeding experienced development by 0.64 units higher than children who were not not exclusively breastfeed. Exclusive breastfeeding can improve early childhood development. Children with success exclusive breastfeeding have no significant value on motor development. This was because there were many confounding factors that can influence the success of exclusive breastfeeding on child development. The motor development of children who were exclusively breastfed was faster and in accordance with the development of children than children with success exclusive breastfeeding (Michels et al., 2019).

Many factors can influence the success of exclusive breastfeeding on children's development. Breast milk was not sufficient to fulfill the needs of the baby so that the baby experienced anxiety and hunger. The digestible component of breast milk made babies always fussy so they did not get comfort and calm. The growth and development of a baby was not only influenced by the nutrition provided but by the environment from the stimulation of parents and caregivers (Menella et al., 2015).

\section{The effect of maternal education on child development}

Higher maternal education $\geq$ Senior high school experienced a corresponding develop- 
ment by 2.45 units higher than mothers with low education and there was a statistically significant positive effect. Mothers with higher education can improve their nutritional status and child development. Maternal education was an important factor in shaping the maternal mindset and character (Kusuma et al., 2017).

Children with highly educated parents tend to pay attention to each child's growth and development (Kusumasari et al., 2016). From the results of study in several countries, it showed that higher education for mothers can reduce the level of low nutritional status, reduce stunting and improve child development accordingly (Alderman et al., 2017).

\section{The effect of maternal employment on child development}

The results of this study showed that child development was affected by maternal employment. Mothers who work outside the home have a negative effect on child development. Children, who should always be with the mother, get attention and stimulation from the mother must be away from mothers who work outside the home causing a lack of interaction between mother and child.

Lack of stimulation provided to children can cause growth and development problems of children. The interaction between mother and child can influence each other's development (Damayanti et al., 2017; Hadi yanto, 2014). Children who were left behind with parents because of work tend to have fewer interactions and can delay emotional physical, cognitive and social development in children. The more time the child and mother together, it would increase the monitoring and attention given by the mother to the child so that it can have a good effect on the child's development (Halu et al., 2017).

\section{The effect of family income on child development}

Family income has a significant influence on children's development. Children with family income $\geq \operatorname{Rp~2,840,000~experienced~child~}$ development according to 1.93 units higher than low family income. Fulfillment of balanced nutrition in children would be more easily fulfilled by children with high-income families (Moriguchi et al., 2019).

Low family income caused limited play and learning facilities for children to perform early stimulation. Inhibition of facilities in conducting early stimulation in children and the provision of food intake that can affect children's development, especially children's intelligence (Bernal et al., 2019; Sinta et al., 2017).

The results of this study were in line with Moriguchi (2019) who stated that family income has a strong influence on children's development. Children with low economic status showed poor brain development function and showed weak prefrontal activation compared to children with high economic status. Fulfillment of balanced nutrition in children would be more easily fulfilled by children with high-income families (Moriguchi et al., 2019).

\section{The effects of early childhood schools on child development}

The results showed that there was a contextual influence on the level of early childhood education on child development (ICC= 10.09\%). Every institution for early childhood education has an effect on development. Education given to early childhood can have a positive impact on overall quality in the preschool environment including the physical environment and the interactions that children give to the environment (Proulx et al., 2019).

Provision of stimulation in early childhood education facilities can determine the quality of growth and development of children as well as determining the quality of subsequent children. Good interaction in the family environment and good support by the surrounding environment can optimize the 
development that occurs in early childhood (Black et al., 2016). The stimulation provided in child educational environment can affect a child's brain that developed very rapidly during a child's early life (Hermoyo, 2014).

The facilities of early childhood education institutions can influence children to be able to play and develop in supporting child stimulation (Rao et al., 2017; Zacarias et al., 2019). Different educational environments give children access to be taught to stimulate development and children have the experience to optimize development (Putriarsih et al., 2017).

This study concluded that early childhood development was influenced by nutritional status, dietary patterns, exclusive breastfeeding, maternal education, maternal employment, and family income. Early childhood education has contextual influence on child development..

\section{AUTHORS CONTRIBUTION}

Dinda Septiani Hardilla as the main author has a role in carrying out the study, collecting study data, formulating research articles, and processing the data. Harsono Salimo played a role in the formulation of the mindset in study. Eti Poncorini Pamungkasari played a role in the formulation of study methods and discussion of study results.

\section{CONFLICT OF INTEREST}

This study used personal funds from the main author.

\section{FUNDING AND SPONSORSHIP}

There is no conflict of interest in this study.

\section{ACKNOWLEDGEMENT}

Acknowledgments were conveyed by author to the Head of Early Childhood Education in Tanjung Jabung Timur who allowed this study to be carried out. Thank you to all children who are willing and cooperative to be the subject of this study.

\section{REFERENCE}

Alderman H, Headey D (2017). How important is parental education for child nutrition. World Dev. 94(17): 448-464. http://dx.doi.org/10.1016/j.worlddev. 2017.02.007.

Bernal R, Ramirez SM (2019). Improving the quality of early childhood care at scale: the effects of "from zero to forever". World Dev. Elsevier. 118: 91-105. http://doi.org/10.1016/j.worlddev.2019.02 012

Black MM, Walker PS, Fernald HL (2016). Early childhood development coming of age: Science through the life course from science to scale. Child Dev. SER. 6(16): 1-14. http://dx.doi.org/10.1016/s01406736(16)31389-7

Bornstein MH, Britto PR, Tarumi YN, Ota Y, Petrovic O, Putnick DL (2012). Child development in developing countries: Introduction and methods. Child Dev. 83(1): 16-31. http://doi:10.1111/j.14678624.2011.01671.x

Damayanti AW, Mundir M (2017). The effect of exclusive breastfeeding and formula milk on the growth and development of infants aged 3-6 months in Posyandu Greenview Malang. Cendikia Utama Jurnal. 6(2): 40-45. https://doi.org/10. 31 596/jcu.v6i2.191

Hadiyanto H (2014). The influence of education, work and parents' income on economic learning achievement in high school students. Jurnal Ekonomi Pendidikan dan Kewirausahaan. 2 (2): 2327. http://dx.doi.org/10.26740/ jepk.v2n2.p171-185

Halu NAS, Murti B, Tamtomo D (2017). Effect of prematurity, birthweight, maternal stress, socio-economic status, and mother-child intimacy in the development of preschool children in Surakarta. J Matern Child Health. 2(3):187- 
Hardilla et al. / Do Early Childhood Schools Have Contextual Effect

199. https://doi.org/10.26911/thejmch.2017.02.03.01

Hati SF, Lestari P (2016). The effect of stimulation on the development of children aged 12-36 months old in Sedayu subdistrict, Bantul. JNKI. 4(1): 44-48. https://dx.doi.org/10.21927/jnki.2016. 4

Hermoyo PR (2014). Establish effective communication during early childhood development. Jurnal Pedagogi. 1 (1): 121. http://dx.doi.org/10.30651/pegi. v1i1.21

Husnah (2015). The Relationship between Dietary Pattern, Growth and Stimulation with the Development of Toddler Children in Posyandu Melati Kuta Alam Banda Aceh. Jurnal Kedokteran Syiah Kuala. 15(5): 66-71. Retrieved from http://jurnal.unsyiah.ac.id/JKS/article /view/3254/3081

Kusuma RI, Salimo H, Sulaeman SE (2017). Path analysis on the effect of birth weight, maternal education, stimulation, exclusive breastfeeding, and nutritional status toward motor development of children aged 6-24 months in Banyumas Regency. J Matern Child Health. 2(1): 67-75. https://doi.org/10.26911/thejmch.2017.02.01.07

Kusumasari R, Tamtamo D, Dewi RLY (2016). The relationship between parental socio-economic status, birth weight, and development in children aged 1-5 years in Surakarta. J Matern Child Health. 1 (3): 195-199. https:// doi.org/10.26911/thejmch.2016.010307

Lindawati (2013). Factors related to motor development of preschool children. Journal Health Quality. 1 (2): 14-21. Retrieved from https://www.poltekkesjakarta1.ac.id/file/dokumen/46JURN AL_LINDAWATI.pdf

Menella JA, Trabulsi JC, Papas MA (2015). Effects of cow milk versus extensive protein hydrolysate formulas on infant cognitive development. Amino Acids. 48(3): 697-705. Doi: 10.1007/s00726015-2118-7.

Michels KA, Ghassabian A, Mumford SL, Sundaram R, Bell EM, Bello SC, Yeung EH (2017). Breastfeeding and motor development in term and preterm infants in a longitudinal US cohort. J Am Clin Nutr. 106(6): 1456-1462. https://doi.org/10.3945/ajen.116.144279

Moriguchi Y, Shinohara I (2019). Socioeconomic disparity in prefrontal development during early childhood. Scientific Reports. 1 (1): 1-8. https:// doi.org/10.1038/s41598-019-39255-6

Proulx, Kerrie, Aboud F (2019). Disaster risk reduction in early childhood education: effects on preschool quality and child outcomes. J. Int. Educ. Dev. Elsevier. 66: 1-7. http://doi.org/10.1016/j.ijedudev. 2019.01.007

Putri AR, Murti B, Indarto D (2016). Effect of nurturing at child care center on gross and fine motoric, language and sosial development in children aged under five years in Ungaran Barat subdistrict, Ungaran. J Matern Child Health. 2(1): 1-9. https://doi.org/1026911/thejmch.2017.02.01.01

Putriarsih R, Prawatiningsih AS, Mulyani S (2017). The relationship of non-formal early childhood education with the deve lopment of children in Gatak District, Sukoharjo Regency. Jurnal Edu Nursing. 1(2): 72-8o. Retrieved from http://journal.unipdu.ac.id/pdf/2017;1(2)

Rao N, Sun J, Chen EE, Ip P (2017). Effectiveness of early chilhood interventions in promoting cognitive development in developing countries: a systematic review and meta-analysis. Hk J Paed. 22: 14-25. Retrieved from http://www. hkjpaed.org/pdf/2017;22;1425.pdf

Risma A, Helmiyati S (2013). Maternal em- 
Hardilla et al. / Do Early Childhood Schools Have Contextual Effect

ployment status was not associated with nutritional status and development of children aged 1-3 years old in Kadia District, Kendal. Jurnal Gizi dan Dietik Indonesia. 1(1): 44-50. http://dx.doi.org/10.21927/ijnd.2013.1(1).4450

Sinta P, Salimo H, Pramungkasari EP (2017). Multilevel analysis on the biosocial and economic determinants of exclusive breastfeeding. J Matern Child Health. 2(4): 356-370. https://doi.org/10.26911/tejmch.2017.02.04.06.

Siswina T, Shahib N (2016). The effect of educational stimulation on the intelligence development of children aged 3-6 years old. Jurnal Ilmiah Bidan. 1(2): 27-33. Retrieved from https://media.neliti.com/media/publications/227204 pengaruh-stimulasi-pendidikan-terhadap-p722bd298.pdf

Solihin RDM, Anwar F, Sukandar D (2013). The link between growth and cognitive and motor development in preschool ers. J Nation Inst of Health. 36 (1): 6272. Retrieved from http://ejournal.litbang.depkes.go.id/index.php/pgm/ar ticle/view/3396/3387

Walker SP, Wachs TD, Gardner JM, Lozoff B, Wasserman G, Pollitt E, Carter J (2007). Chil development: risk factors for adverse outcomes in developing countries. Child Dev. Lancet. SER. 369: 145-57. Retrieved from https://www.who.int/maternal_child_adolescent/documents/pdfs/lancet_child_dev_series_paper2.pdf

Zacarias G, Shamah T, Elton PE, Garbus P, Garca O (2019). Development of an intervention program to prevent childhood obesity targeted to Mexican mothers of school aged children using inter vention mapping and social cognitive theory. Evaluation and Program Planning. http://doi.org/10.1016/j.evalprogplan.2019.02.008 